\title{
EU-OSCE Inter-Institutional Interaction: Preventing Water-Related Conflict in Central Asia
}

\author{
Licínia Simão
}

Published online: 5 December 2012

(C) CEEUN 2012

\begin{abstract}
Inter-institutional interactions remain a largely under-theorized area in International Relations, despite their pertinence in the context of the post-Cold War restructuring of pan-European institutions. Moreover, the ongoing debates on 'mutually reinforcing', 'interlocking' or 'interblocking' institutions further increases the relevance of these issues for regional stability. Departing from this context, and building on field research in Central Asia, the article looks at how the Organisation for Security and Cooperation in Europe (OSCE) and the European Union (EU) are interacting with each other in the Central Asian context, in the field of conflict prevention in water-management. Drawing on the framework of source and target institutions, the article looks at how the two institutions interact in this regional context, with a focus on water management policies. The overall conclusion indicates that, in the absence of strategic vision on how the two organisations might reinforce each others' work, the learning processes which have historical taken place within the OSCE have been neglected by EU member states and the EU itself, seeking instead to make an instrumental use of the OSCE, regarding the issue of water-management.
\end{abstract}

Keywords European Union · OSCE · Central Asia · Water management · Inter-institutional interaction

\section{Introduction}

This article deals with the issue of inter-institutional interaction in Central Asia. The main purpose is to map the frameworks through which interaction between institutions operating in Kazakhstan, Kyrgyzstan, Tajikistan, Turkmenistan and 
Uzbekistan occurs, looking at two specific institutions and their interaction on conflict prevention on water related issues: the Organisation for Security and Cooperation in Europe (OSCE) and the European Union (EU). The reason for addressing the interactions between these two institutions lies, partly, in the similar nature of their objectives and overlapping membership. Moreover, the OSCE has had an important presence in Central Asia since these countries' independence from the Soviet Union, in the early 1990s, which makes it a leading institutional framework for cooperation with and within the region, as well as a potential learning space for a new-comer, such as the EU.

The EU and the OSCE are two important pillars in the post-Cold War panEuropean regional security order, and the quality of their inter-institutional interaction is a necessary condition for stability and peace to endure in this geographical space. There are important examples of both organisations cooperating in conflict prevention and crisis management operations in the Balkans and the South Caucasus, and it is therefore relevant to inquire about the nature of their interaction in Central Asia, which has traditionally been regarded as a niche of the OSCE. As the EU developed its strategy for Central Asia, in 2007 (Council of the European Union 2007), and became engaged in issues of regional peace and stability, the potential for overlapping and 'interblocking' increases, creating problems not only for the institutions themselves, but also to the effectiveness of their work in the region. Despite the cooperative efforts promoted in 1999, with the establishment of the Platform for Co-operative Security (OSCE 1999a), which recognised the need to work on the basis of equality and spirit of partnership and to avoid the 'creation of a hierarchy of organisations or a permanent division of labour' (OSCE 1999b, p. 43), hierarchisation did take place. As Peters (2004, p. 384) has argued, the EU and NATO gained greater political flexibility and expanded their responsibilities, whereas the OSCE was marginalised (Bailes et al. 2008, p. 67). In the Balkans, for instance, the EU had a decisive impact on the OSCE minoritiesrelated projects, and eventually the OSCE field missions there were closed as the process of accession to the EU advanced (Stewart 2008, p. 275). The EU's increased role in the South Caucasus, after 2008, further contributes to this marginalisation (for more details see Evans 2008; Stöber 2011), which the new Corfu process has been unable to prevent (see Bakoyannis 2009).

Considering this, the article takes water-management as a case study to analyse EU-OSCE interaction. Both organisations have underlined the importance of addressing water resources' management as an issue of regional interest in Central Asia, promoting dialogue at the highest political level, in order to establish a regulatory and institutional framework, through which grievances can be addressed and peaceful long-term management be pursued. Moreover, water-related conflict can also emerge at the local level, within and across communities, escalating into open confrontation, demanding a socio-economic perspective on the issue, which both organisations are well placed to develop.

Thus, the article begins by defining the analytical approach to address interinstitutional interaction, using the idea of a source and target institution framework (van Ham 2009). This makes the central question of the article focus on whether the OSCE has retained its position as a source institution, leading the process of 
knowledge transfer towards the EU, or whether the EU has been able to become autonomous. In order to answer this question, the article deals with the presence of the two organisations in Central Asia, paying particular attention to their agendas, approaches, and their impact on policy-making on the environmental and economic dimension. The article finishes by addressing specific cases where joint EU-OSCE 'water diplomacy' could be enhanced, including the promotion of regional cooperation and the management of the water-energy nexus. The overall conclusion indicates that, in the absence of strategic vision on how the two organisations might reinforce each other's work, the learning processes which have historically taken place within the OSCE have been neglected by EU member states and the EU itself, seeking instead to make an instrumental use of the OSCE, regarding the issue of water-management.

\section{Inter-Institutional Interaction: An Analytical Framework}

Inter-institutional interactions remain largely understudied, making strong theoretical frameworks unavailable (Oberthür and Gehring 2003). Traditional approaches to International Organisations (IOs) and their roles in international affairs have often pictured them as arenas for inter-state bargain (see Mearsheimer 1994) or alternatively as comprising a certain level of 'actorness' in the international system (see Barnett and Finnemore 1999; March and Olsen 1998). By recognising that interaction between organisations goes beyond the advancement of member states' interests, it is then possible to look at how institutions mutually-shape each other's views, identities and approaches, in a socially constructed understanding of international relations. This learning ability of institutions is not without its limits. The re-arrangement of the pan-European institutions after the Cold War, has evidenced not only the institutions' struggle for permanence and survival, but also their inability to accommodate mandates and capabilities in a mutually reinforcing way, often privileging a duplication of efforts over coordination (Gowan and Batmanglich 2009).

Developed in the post-Cold War context, the notion of 'interlocking institutions' was put forward in the Rome Declaration of the North Atlantic Treaty Organisation (NATO), in 1991, and sought to combine NATO's work with the Conference for Security and Cooperation in Europe (CSCE), the European Communities, the Western European Union and the Council of Europe, in an interlocking security architecture (Aybet 2000) that would assure stability in Europe, but also the permanence of the hegemonic post-Cold War order (Ikenberry 2001). The existing hegemonic arrangements, based on US leadership within a multilateral framework were regarded as the most effective way to assure peace and stability in the international system. Although conceptually it seemed to make sense to coordinate the work of these mutually reinforcing institutions in the consolidation of a liberal democratic order in the pan-European space, this purpose encountered many difficulties. The emergence of compatibility and coordination problems led some to view these institutions as 'interblocking', rather than 'interlocking' (Kintis 1998; Weisbrode 2009). Institutional jealousy and apprehension, as well as the 
development of different security cultures have made interaction harder and less fruitful, leading to duplication of efforts, mismanagement of resources and contradicting approaches. However, cooperation between institutions in the panEuropean space has not been exclusively negative and there have been examples of mutual support and commitment to common purposes, which make the study of these interactions all the more urgent and necessary.

Although this article does not make an extensive analysis of interaction patterns, it builds on previous work on EU-OSCE interaction to see how these processes change in the Central Asian context of water-management. Van Ham (2009) analysed the interaction between the EU and the OSCE from a historicalinstitutional perspective in order to establish a causal pathway and mechanisms of influence, interacting in the process. The central elements of the concept of interaction include a source institution, a target institution and a causal pathway, which accounts for the identified outcome (Oberthür and Gehring 2003). For analytical reasons he looked at the EU as the source institution and the OSCE as the target institution, and took processes of 'knowledge' transfer, in the form of ideas, reports, information exchange in these institutional settings, and (political) 'commitments' agreed by member states of both organisations as the two central mechanisms of influence. His conclusions showed that, although the OSCE's approaches to security have influenced the EU's conceptualisation as an emergent security actor, this influence has been at times reversed. This means that the EU has increasingly seen itself as a model for others to emulate and has tried to coordinate its member states' preferences and stances in other institutional settings, namely in the OSCE (van Ham 2009, p. 133). The EU has acted as a leading source institution in shaping OSCE perspectives and policies, using processes of persuasion and learning (acting through knowledge) as well as the previous political commitments agreed by the EU member states within the EU, which are later transferred to the OSCE institutional space. This situation gave rise to new dynamic processes of interaction between the two actors, sometimes leading to coordination, others to competition.

The working hypothesis for this article is that in the context of Central Asia, the OSCE has retained its position as the source institution, providing knowledge transfers to the EU, facilitated by their overlapping membership and by the OSCE's extensive field presence and political legitimacy in this regional context. However, to the extent that the OSCE has been unable to modify EU's (or relevant actors' inside the EU) behaviour or its constellation of interests in Central Asia, we might witness an inversion of roles, with the EU increasing its competition with the OSCE, under the banner of what van Ham (2009) calls a 'strategic partnership', in which the EU would seek to use the OSCE's geographical reach to its own advantages. Although EU member states have regarded the OSCE as the forum where environmental and economic issues should be addressed in the Central Asian context; with the development of its own strategy for the region, the potential for synergies has decreased, and in a best-case scenario, both organisations have yet to fully develop an operational road map for cooperation. 


\section{OSCE and EU in Central Asia: The Economic and Environmental Dimension}

\section{The OSCE in Central Asia}

The OSCE's third basket (economic and environmental issues) has remained underdeveloped, when compared to the political and military and human dimensions. Illustrating this, only in 1997 was the position of the Co-ordinator of OSCE Economic and Environmental Activities created, within the OSCE Secretariat, and only at the Ministerial Council meeting in Maastricht, in December 2003, did the Participating States adopt the OSCE Strategy Document for the Economic and Environmental Dimension (OSCE 2012). Moreover, although Central Asian leaders (and Moscow) had pressured the organisation to become more actively engaged in this third dimension, it was not until 1998, that the first expert in economic and environmental issues arrived in Central Asia, hosted by the OSCE Central Asia Liaison Office (CALO), in Tashkent (Dorenwendt 2000, p. 320).

The expectations in Central Asia towards the OSCE's economic dimension proved too high, including demands for the organisation to finance large scale projects and help these countries attract Foreign Direct Investment (FDI) (Raballand 2004, p. 150). However, the OSCE organised its presence in Central Asia around field offices, whose mission was to provide information on the region and act as early-warning centres. As one OSCE Ambassador in the region has put it 'the OSCE has "boots on the ground", giving it a privileged set of contacts and a more visible and politically engaged presence. ${ }^{1}$ Overall, the OSCE has adapted its presence to the new realities in Central Asia and has sought to profile itself as a partner to local actors (Freire 2010, p. 55). Finally, the economic dimension has suffered from two related problems: on the one hand, most of its European participating states have pushed for a more visible role in the human dimension, making the so-called third basket a secondary aspect in the organisation's work. On the other hand, the OSCE was also seen as promoting an approach that many Central Asian leaders did not share or sponsor, and its focus on a regional dimension, not least in the environmental and economic dimensions, rapidly proved inadequate in the absence of local ownership (Shkolnikov 2009, pp. 295-297).

The organisation of annual Economic Forums, gathering all states of the OSCE area and aimed at debating major themes chosen by the acting Chairmanship in Office $(\mathrm{CiO})$, has been an important instrument to promote cooperation among the OSCE and other international actors, such as the EU, as well as cooperation among Central Asian states. In May 2002, under the Portuguese CiO, the 10th Economic Forum gathered in Prague, to debate the issue of 'Co-operation for the sustainable use and the protection of quality of water in the context of the OSCE'. From the preparatory documents it is visible that a major objective of the OSCE was to act as a facilitator and co-ordinator among Central Asian states and international donors (OSCE 2002a). The OSCE sought to promote consensus and economic cooperation among Central Asian states, including the signing of agreements on trans-boundary

\footnotetext{
1 Interview with Ambassador Andrew Tesoriere, Head of the OSCE Field Mission in Bishkek, Kyrgyzstan, 29 January 2010.
} 
cooperation and confidence-building measures. No major advances or commitments were achieved in this meeting, with the focus towards regional security and stability, linked to counter-terrorist efforts (OSCE 2002b). However, it is noteworthy that in December 2003, the OSCE finally adopted a Strategic Document for the Economic and Environmental Dimension (OSCE 2003). In that year the OSCE also established a partnership with the United Nations (UN) to create the Environment and Security Initiative (ENVSEC), a central tool to assess and address environmental problems which could threaten security, stability and peace in South Eastern and Eastern Europe, the South Caucasus and Central Asia. ${ }^{2}$

Cooperation with the UN seems to be particularly suited to the demands of the environmental and economic dimension, especially when compared with cooperation with the EU. Not only because the UN family has a longer and more widespread presence in Central Asia, but because it is also more easily accepted by most donors and local actors as a legitimate interlocutor. In fact, in 2006, the OSCE, together with the UN Economic Commission for Europe (UNECE) and a large group of international donors, managed to promote the establishment of the ChuTalas Commission, which regulates and monitors the joint use of water from the Chu and Talas rivers by Kazakhstan and Kyrgyzstan. ${ }^{3}$ The project drives on the widely shared notions among water management experts that one of the central aspects avoiding water-related conflict is the development of institutional frameworks for cooperation (Wolf et al. 2005). That same understanding has been shared by the EU, in its approaches to water management in Central Asia.

\section{The EU and Central Asia}

The EU streamlined its policies towards Central Asia through the development of a common EU strategy for the region, in 2007. This late engagement reinforces our argument that the EU and its member states relied on the OSCE to develop a common understanding of the region. Thus, the development of a common EU presence and the redefinition of its interests and cooperation instruments through the adoption of the EU strategy on Central Asia were meant to make its presence more visible. The strategy proposes a coordinated approach of the EU to water management (Council of the European Union 2007). It lists 'environmental sustainability and water' as one of the central issues in its cooperation with Central Asia. Under this headline, the EU is promoting Integrated Water Management, the achievement of the Millennium Development Goals (clean drinking water and good sanitation facilities) and regional security, stability and economic development as major goals (Council of the European Union 2007, pp. 21-22).

Two further aspects are worth mentioning, regarding the EU's views on water issues in Central Asia. The first is that the EU, despite the lack of results over the last 20 years, still underlines that water management needs to be addressed from a regional perspective. Although in theory, this is a rational option, the practical examples show that full inclusive regional cooperation on water has been very

\footnotetext{
${ }^{2}$ More information available at http://www.envsec.org/index.php. Accessed 27 April 2010.

3 More information available at http://www.chutalascommission.org/eng. Accessed 27 April 2010.
} 
limited and often more rhetoric than effective. The OSCE and other donors engaged with the region recognise the deep political obstacles to such cooperation. ${ }^{4}$ Innovative solutions could include variable geometry cooperation among regional states and other stakeholders, such as private companies, Non-Governmental Organisations, donors, etc. Clear incentives to regional cooperation should also be made available, as was done in the past. ${ }^{5}$

The second issue is the link made by the EU Strategy on Central Asia between water and energy security. In the words of the strategy '[b]esides oil, gas and electricity, water management is a decisive aspect of [EU] energy cooperation with Central Asia' (Council of the European Union 2007, p. 18). It is therefore in the EU's interest to promote an integrated approach to energy security in the region, where water management will be a central issue. Although the analysis of the dynamics underlying the water-energy nexus in Central Asia is beyond the scope of this article, this remains a central issue, and one which the EU has acknowledged and could promote among other donors in the region, as suggested in its strategy (see Fumagalli 2008; The World Bank 2004; Libert et al. 2008).

A major EU initiative in Central Asia is the EU Water Initiative (EUWI), which aims to promote the principle of Integrated Water Resource Management (IWRM), and water-related Millennium Development Goals. ${ }^{6}$ The EUWI is based on National Water Policy Dialogues, looking to adapt activities to the needs of each partner country. There is one on-going National Water Policy Dialogue being implemented with Kyrgyzstan and similar processes are being developed with Tajikistan and Turkmenistan. Moreover, the German GTZ is also promoting another set of projects under the headline of 'Transboundary Water Management in Central Asia', which aim at developing capacity of the institutions responsible for water management. These projects however, do not have any specific mechanism of coordination with the OSCE, missing the potential for positive synergies to develop.

\section{Overlapping and Competing Views on Water Resources in Central Asia}

Overall there is great scope for overlap and cooperation, namely in the promotion of a clearer political approach to the issue of water management, involving different stakeholders in the region. Surprisingly, the view in the field is slightly different, as neither the EU nor the OSCE are seen as particularly well positioned to forge a regional political consensus on how to address these issues. ${ }^{7}$ Moreover, the two

\footnotetext{
${ }^{4}$ Interview with Kimberley Bulkley, Economic and Environmental Officer, OSCE Centre in Bishkek, Kyrgyzstan, 29 January 2010. Comments by Jackie Charlton, Senior Regional Governance Advisor, Department for International Development (DFID), Bishkek, Kyrgyzstan, 7 May 2010.

5 Immediately after independence from the Soviet Union, the creation of regional mechanisms for cooperation on water management was achieved, among other approaches, by making it a central condition for assistance to be disbursed. This was a policy pursued, namely by the World Bank. See Sokolov et al. (n/a).

${ }^{6}$ Email Exchange with Delphine Marié, Project Manager, Environment and Water Operations Section, Delegation of the European Union to the Republic of Kazakhstan, 2 March, 2010.

7 Interview with Ambassador Andrew Tesorière, Head of the OSCE Centre in Bishkek, Kyrgyzstan, 29 January 2010.
} 
organisations need to address problems in their bilateral relations in Central Asia, which could prove hard to overcome. Although the EU and the OSCE could be seen as ideally complementing each other's work, the reality on the ground is far more complex.

Firstly, the two organisations display different natures, in their relations with Central Asian states. Whereas the OSCE is a political organisation to which Central Asia is part, the EU so far has been a donor organisation in the region. This has implications for the nature of the activities each organisation pursues, and therefore on how they can mutually engage in developing a common approach to regional problems. The environmental and economic dimension is particularly suited to engage in small, locally-based projects in Central Asia, where the OSCE field offices have good expertise and flexibility to address issues when they arise. This could mean in practice a greater turn to inter-community conflict prevention and development activities, which however, is not the OSCE's main purpose. ${ }^{8}$ Inversely, the EU has maintained a low political profile, owing not only to the lack of legitimacy, but mainly due to the lack of personnel in its delegations in Central Asia. ${ }^{9}$ Although there is political conditionality attached to the EU's development aid, regional political dialogue has remained a largely unachieved goal, despite the fact it is the most important aspect in regulating water management in the region.

The case could then be argued that, the EU and the OSCE could actually complement each other's work in Central Asia. The OSCE could engage in political dialogue with the leaders in the region, working as a platform with other partners and local governments, and using its extensive field presence. The EU, on the other hand, could then more effectively disburse its assistance and implement its strategy for Central Asia. Moreover, this seemingly obvious complementarity (what has been called a 'marriage in heaven' ${ }^{10}$ ) could also mean an effective coordination of political pressure and the development of a coordinated dialogue with local leaders that could be more effective in pushing for commitments in regional cooperation. Such interaction would draw on each organisation's major strengths and complement each other's work.

Nevertheless, the reality today is rather different. Two sets of issues compete to make regional water management in Central Asia an area where the OSCE-EU cooperation has been minimal and unsuccessful in changing the current situation. On the one hand, there is no plan on how to render this approach operational and on how to develop synergies between the two institutions. The issue of which organisation might take the lead in this matter could draw on the perceived legitimacy of the OSCE, on the one hand, and on the EU's overall strategic planning, on the other. Besides these issues, there is also a clear difference of scale and of bureaucratic styles. The EU is a more rigid structure in terms of its allocation of funds and project management, whereas the OSCE is more flexible in its

\footnotetext{
${ }^{8}$ Interview with Kimberly Bulkley, Economic and Environmental Officer, OSCE Centre in Bishkek, Kyrgyzstan, 29 January, 2010.

9 Meeting with EU Delegation Officials, Bishkek, 29 April 2010.

${ }^{10}$ Interview with Ambassador Andrew Tesorière, Head of the OSCE Field Mission in Bishkek, Kyrgyzstan, 29 January 2010.
} 
disbursement of funds. Moreover, the EU is better suited for long-term planning and, based on its Strategy for Central Asia, to develop its own projects, while the OSCE works often as a mediator and can address specific issues when they arise. EU subcontracting the OSCE in certain situations, or even directly funding OSCE projects, is a possibility to make the best use of these differences. However, this could amount to making the OSCE a 'middle man', bound by EU rules, something that is not welcomed, whether in field offices or in Vienna. ${ }^{11}$ This is a clear example of the institutional hurdles preventing the EU from taking a leading role in the region, by resorting to OSCE legitimacy and presence.

The second set of issues limiting regional cooperation on water in Central Asia relates to the states of the region. During the Soviet period, interdependence was reinforced due to central planning activities, including the establishment of swaps of water and energy regulated from Moscow (see Karaev 2004). In the final years of the Soviet Union, two water basin organisations for the Amu-Darya and the SyrDarya were established and a regulatory scheme for trade-offs on water, agriculture and energy was established between the republics and managed from Moscow (Sokolov et al. n/a). In 1992, these two organisations were merged under a new agreement on Cooperation in the Joint Use and Protection of Water Resources of Interstate Significance, and an Interstate Commission for Water Coordination (ICWC) was established by the five Central Asian republics. A further step in the institutionalisation of regional water relations was the creation of the Interstate Council of the Aral Sea (ICAS) and the Interstate Fund for Saving the Aral Sea (IFAS). Despite these important steps, regional cooperation has remained a formal and largely inconsequential process, and breaches of the agreements have been constant (Eurasian Development Bank 2008, p. 15). International actors have been unable to pull their weight together to press local decision-makers into renewed agreements that assure the well-being of all involved. Neither the OSCE, discussing the issue internally, neither the EU through the use of political conditionality and coordination with other donors have been successful in this regard, suggesting that 'interblocking' dynamics have been at play.

Moreover, the states of the region have been subject to competing dynamics, as far as water resources are concerned, linking privatisation and market-prices in the energy sector, with high dependence on water for agricultural purposes. The commoditisation of water and the rising competition for Central Asian oil and gas has thus aggravated the lack of incentives for the observance of regional agreements. Projects by Kyrgyzstan and Tajikistan to build new Hydropower Plants (HPPs) have escalated tensions on issues of timing in the retention and use of water (Hogan 2000; Eurasian Development Bank 2008, pp. 18-28). Occasionally, energy cuts have also been used by downstream countries as a pressure tool on their neighbours. Uzbekistan has been particularly keen on these tactics towards Kyrgyzstan as a response to water shortages (Khamidov 2009, see also Parshin 2010 for environmental arguments), at times with potential for inter-state violence, as was the case in 1997 (see Karaev 2005). Further competition for access to Central Asian energy resources will potentially make the barter agreements negotiated

11 Interviews, OSCE officials in Bishkek, 29 January, 2010. 
among the countries of the region harder to fulfil. It will be much more profitable to sell oil and gas to third countries than to swap them for water with neighbouring countries. EU member states and Russia (as well as China) are competing for access to these resources, potentially undermining regional energy and water security. In that sense, the overlapping membership of the EU and OSCE has not been fully used to discuss these matters and both organisations seem more interested in the advancement of its member states' interests than in socialising them into new approaches and views.

\section{Conclusions}

The complex nature of water relations in Central Asia, including its multi-faceted nature, is better suited for comprehensive approaches and a division of labour among international donors. Nevertheless, it is also clear that despite ongoing efforts to improve water management in Central Asia since independence from the Soviet Union, the lack of political will by regional governments to develop such comprehensive frameworks and the politicisation of water have been major factors of instability. This context has been underlined both by the EU and the OSCE as a central obstacle to the two organisations' efforts to promote regional cooperation and improve regional stability.

Sharing similar challenges, a mutually reinforcing approach towards Central Asian regional water problems could prove a wiser policy. This was visible in the efforts of some of the European CiOs, trying to put the topic on the OSCE's agenda, and trying to step the organisation's profile as a coordinating body. Moreover, EU member states have also regarded the OSCE as a valuable forum to develop relations with Russia and the CIS states, despite limited results. Similarly, the EU itself has learned from the OSCE's long-term presence in Central Asia, and the exchange of information between the two organisations in Vienna is well established. However, there has not been advancement into a strategic vision on how to jointly address the issue of water management and, on the ground the two organisations find it increasingly hard to coordinate efforts.

As far as environmental activities are concerned, the dynamics of interaction between the EU and the OSCE in Central Asia seem to illustrate a different pattern. That is, although initially the OSCE expertise was the main factor shaping EU policies towards Central Asia and the organisation was regarded as the natural place to address regional challenges; after the adoption of the EU Strategy for Central Asia, the EU has clearly devised an independent role for itself. This has meant that the EU has sought to combine a developmental approach, through the funding of projects and infrastructures, with a political one, even if quite limited on regional water management. As argued before, the lack of an operational framework on how to better complement each other's work in Central Asia and on how to overcome the lack of political will for regional cooperation has limited the ability of these two organisations to achieve results, and has similarly made their interaction ineffective, as regards economic and environmental issues in this region. 
Acknowledgments This article is the result of a Teaching and Research Fellowship, granted by the OSCE Academy, Kyrgyzstan, from January to May 2010. The author would like to thank the participants in the seminar at the OSCE Academy, Bishkek, Kyrgyzstan, 7 May 2010, and the participants at the panel on "The EU in a Community of International Organizations", at the ISA Annual Convention 2011, in Montreal, for their valuable comments on previous drafts of this article.

\section{References}

Aybet G (2000) A European security architecture after the cold war: questions of legitimacy. MacMillan, London

Bailes AJK, et al. (2008) Reflections on the OSCE-EU Relationship. In: OSCE yearbook 2007. Baden Baden, Nomos, pp 65-77

Bakoyannis D (2009) Opening remarks by the foreign minister and OSCE Chairperson at the Corfu Meeting with OSCE Foreign Ministers, 28 June

Barnett M, Finnemore M (1999) The politics, power, and pathologies of international organizations. Int Organ 53(4):699-732

Council of the European Union (2007) European Union and Central Asia: strategy for a new partnership, October

Dorenwendt T (2000) The OSCE Central Asia Liaison Office. In: OSCE yearbook 1999. Baden Baden, Nomos, pp 317-325

Eurasian Development Bank (2008) Water and energy resources in Central Asia: utilization and development issues, Industry Report, 28 April

Evans G (2008) European Geopolitics after the Russia-Georgia War: The security role of the OSCE. Keynote Address by the President of the International Crisis Group, to OSCE Parliamentary Assembly, 'The OSCE in an Open World: Trade, Security and Migration', Toronto, 18 September

Freire MR (2010) The OSCE in the New Central Asia. In: Kavalski E (ed) The 'New' Central Asia. The regional impact of international actors. World Scientific, London, pp 49-70

Fumagalli M (2008) The 'food-energy-water' nexus in Central Asia: regional implications of and the international response to the crises in Tajikistan. EUCAM Policy Brief, 2, October

Gowan R, Batmanglich S (2009) Too many institutions? European security cooperation after the cold war. In: Jones BD, Forman S, Gowan R (eds) Cooperating for peace and security: evolving institutions and arrangements in a context of changing US Security Policy. Cambridge University Press, Cambridge, pp 80-97

Hogan B (2000) Decreased water flow threatens cotton crop, peace in region, EurasiaNet, 1 August. http://www.eurasianet.org/departments/environment/articles/eav080200.shtml. Accessed 25 October 2012

Ikenberry J (2001) After victory. Princeton University Press, Princeton

Karaev Z (2004) Managing the water resources in Central Asia: is cooperation possible? Paper prepared for the workshop 'Resources, Governance and Civil War', European Consortium for Political Research Joint Sessions of Workshops, University of Uppsala, 14-18 April

Karaev Z (2005) Water diplomacy in Central Asia, The Middle East review of international affairs, 9(1). http://meria.idc.ac.il/journal/2005/issue1/jv9nola5.html. Accessed 3 May 2010

Khamidov A (2009) Kyrgyzstan: Bishkek and Tashkent weigh gas and water concerns, EurasiaNet, 14 October. http://www.eurasianet.org/departments/insightb/articles/eav101409a.shtml. Accessed 3 May 2010

Kintis A (1998) NATO and the WEU: interlocking or interblocking institutions? NATO Research Fellowships Programme

Libert B, Orolbaev E, Steklov Y (2008) Water and energy crisis in Central Asia. China Eurasia Forum Q 6(3):9-20

March JG, Olsen JP (1998) The institutional dynamics of international political orders. Int Organ 52(4):943-969

Mearsheimer JJ (1994) The false promise of international institutions. Int Secur 19(3):5-49

Oberthür S, Gehring T (2003) Investigating institutional interaction: toward a systematic analysis. Paper for the 2003 International Studies Association Annual Convention, Portland, Oregon, 26 February-1 March 
OSCE (1999a) Operational document - the platform for co-operative security, included in the Charter for European Security, adopted at the Istanbul Summit

OSCE (1999b) Charter for European Security, Istanbul Summit

OSCE (2002a) Tenth meeting of the economic forum. Economic forum (Senior Council), Prague, 28 to 31 May, EF.GAL/13/02, 24 June

OSCE (2002b) Statements by the ministerial council. Tenth Meeting of the Ministerial Council, 6 and 7 December

OSCE (2003) OSCE strategy document for the economic and environmental dimension. Ministerial Council, Maastricht, 2 December, MC(11).JOUR/2

OSCE (2012) Factsheet of the office of the co-ordinator of OSCE Economic and environmental activities. http://www.osce.org/publications/eea/2008/01/29296_1010_en.pdf. Accessed 26 October 2012

Parshin K (2010) Uzbek leaders complain about pollution amid water row, EurasiaNet, 30 April http://www.eurasianet.org/node/60959. Accessed 3 May 2010

Peters I (2004) The OSCE, NATO and EU within the 'network of interlocking European Security Institutions': hierarchization, flexibilization, marginalization. In: OSCE yearbook 2003. BadenBaden, Nomos, pp 381-402

Raballand G (2004) Is the OSCE's economic and environmental dimension relevant in Central Asia? In: Sabahi F, Warner D (eds) The OSCE and the multiple challenges of transition: the Caucasus and Central Asia. Ashgate, Aldershot, pp 149-158

Shkolnikov VD (2009) Missing the big picture? Retrospective on OSCE strategic thinking on Central Asia. Secur Hum Rights 20(4):294-306

Sokolov V et al. (n/a) Transboundary: regional water management cooperation in Central Asia. Case study from the global water partnership tool box. http://www.gwptoolbox.org/images/stories/ cases/en/cs_351_centralasia_full.pdf. Accessed 26 April 2010

Stewart EJ (2008) Restoring EU-OSCE cooperation for Pan-European conflict prevention. Contemp Secur Policy 29(2):226-284

Stöber S (2011) The failure of the OSCE mission to Georgia-what remains? In: OSCE yearbook 2010. Bade Baden, Nomos, pp 203-220

The World Bank (2004) Water energy nexus in Central Asia. Improving regional cooperation in the Syr Darya Basin. Europe and Central Asia Region

Van Ham P (2009) EU-OSCE relations-partners or rivals in security? In: Jorgensen EK (ed) The European union and international organizations. Routledge/Garnet Series, New York, pp 131-148

Weisbrode K (2009) EU and NATO: interlocking or interblocking? Atlantic Council, 1 May. http//www.acnus.org, 07.12.2009. Accessed 3 May 2010

Wolf A, et al. (2005) Managing water conflict and cooperation. In: The World watch institute state of the world 2005: redefining Global security. World Watch Institute, Washington, DC, pp 80-95 